\title{
Addressing the Modelling Precision in Evaluating the Ecosystem Services of Coastal Wetlands
}

\author{
Baodi Sun ${ }^{1,2,3,+}$, Yinru Lei ${ }^{1,2,3,+(\mathbb{C})}$, Lijuan Cui ${ }^{1,2,3, *}$, Wei Li ${ }^{1,2,3}$ (D) $^{\text {, Xiaoming Kang }}{ }^{1,2,3}$ and \\ Manyin Zhang ${ }^{1,2,3}$ \\ 1 The Institute of Wetland Research, Chinese Academy of Forestry, Beijing 100091, China; \\ sunbaodi0927@126.com (B.S.); leiyinru@126.com (Y.L.); wetlands207@163.com (W.L.); \\ xmkang@ucas.ac.cn (X.K.); cneco@126.com (M.Z.) \\ 2 Beijing Key Laboratory of Wetland Ecological Function and Restoration, Beijing 100091, China \\ 3 Beijing Hanshiqiao National Wetland Ecosystem Research Station, Beijing 101399, China \\ * Correspondence: lkyclj@126.com; Tel.: +86-10-6282-4151 \\ + These authors contributed equally to this work.
}

Received: 25 December 2017; Accepted: 4 April 2018; Published: 10 April 2018

\begin{abstract}
Wetlands are one of the world's most productive ecosystems, and therefore it is crucial that management decisions regarding wetlands incorporate awareness of accurate assessments of the value of their respective ecosystem services. In this paper, we seek to improve the modelling precision in the scale transform process of ecosystem service evaluation. Firstly, we selected eight services as the criteria to calculate wetland ecosystem values: substance production, flood control, carbon sequestration, gas regulation, climate regulation, wave reduction, adding new lands, recreation and education. Then, six coastal wetlands of Liaoning province were chosen as the case study areas, and their ecosystem values were calculated by empirical method. Next, we simulated ecosystem values of the six cases by two spatial-scales transform methods named meta-analysis and wavelet transform. Finally, we compared the two groups of simulated values with the empirical measured values to examine their evaluation precisions. The results indicated that the total precision of the wavelet transform model (0.968) was higher than that of meta-analysis (0.712). In addition, the simulated values of single services such as substance production, flood control, carbon sequestration, gas regulation, and climate regulation were closer to the measured values using wavelet transform model. This research contributes to identifying an evaluation model with higher precision for evaluating wetland ecosystem services in the process of scale transform.
\end{abstract}

Keywords: model precision; meta-analysis; wavelet transform; spatial scales transform; coastal wetlands

\section{Introduction}

Increasing attention has been paid to the evaluation of wetland ecosystem services from resource managers, researchers, and the wider public [1-5]. The evaluation can monetize and quantitatively illustrate the values of wetland ecosystem services, strengthening the public's awareness of protecting wetlands [6,7]. Located in the confluence of fresh and saltwater ecological systems, coastal wetlands with high productivity and biodiversity provide rich material and a number of ecosystem services for human beings, such as raw materials, food production, carbon sequestration, wave reduction, climate regulation, and gas regulation, etc. [6,8-10]. Moreover, some coastal wetlands located along bird migratory routes, such as the large tidal flats of the Chinese coastal wetlands, supply food for millions of birds travelling across East Asia and Australia [11,12]. Thus, coastal wetlands are not only important for human survival, in particular for those relying on local fish, but also for the survival of millions of 
migratory birds and other organisms. However, the ecosystem services provided by coastal wetlands vary according to special scales when calculating the ecological and geographical processes $[13,14]$. Errors exist when evaluating the ecological services of large-scale coastal wetlands since they are not as simple as the sum of small pieces of coastal wetlands [15]. Thus, methods for scale transformation of coastal wetland ecosystem service evaluation are particularly urgently needed $[16,17]$.

Two methods, named meta-analysis and wavelet transform, are actively used for larger scale wetland ecosystem service estimation in contemporary research [18-22]. Meta-analysis is a commonly used scale transform method that can attain the value per unit area by adjusting the function [23,24]. Through statistical integration and systematic reviews of previous research, meta-analysis can obtain comparatively accurate values on large scales by value transfer functions [19]. However, meta-analysis is still criticized for its credibility for the extraction and analysis of spatial information since the results generated by its value transfer functions are still services value per unit $[15,25]$. By contrast, wavelet transform can localize the space scales (i.e., it has the performance to localize large-scale wetlands) to balance the wavelet coefficients of the localization space. It can also provide multi-scales of resolution from large to small and an arbitrary direction of rotation, which can be used to extract the directional characteristics of wetlands [26,27]. Clustering aims to detect groups and assign labels to the objects based on the cluster that they belong to. The grid based algorithm quantizes the space into a finite number of cells and then carries out operations on this space.

Some previous research has used meta-analysis and wavelet transform for wetland ecosystem service estimation [19,23]; however, few of them compared the model precisions of these two methods. Thus, in this paper, we seek to explore whether these two methods give consistent results when assessing the ecosystem services values of the same wetland. This research contributes to identifying a more accurate and efficient scale transform method for wetland evaluation at a larger space-scale, providing a technique tool for establishing wetland ecological compensation systems at different spatial patterns, conducting large-scale wetland protection projects, and accounting for green GDP [28-31]. The high-precision model can also be used in evaluating the ecological services of cross-regional, national and even international wetlands in further application.

\section{Methods}

\subsection{Study Site Description}

The study sites are located along the northeast coast of China, delimited by Yalujiang Estuary to the east and Shanhaiguan Old Faucet to the west. The study contains approximately $2920 \mathrm{~km}$ of coastline (Figure 1). The coastal wetland area in Liaoning province is nearly 713,200 ha, which constitutes $51.10 \%$ of the total wetlands in Liaoning Province. Liaoning Province is the only coastal province in northeast China. The mainland coastline within the territory accounts for $12 \%$ of the total length of the coastline through the whole nation [32].

Six wetlands in Liaojing province, named Liuguhe wetland, Linghe estuary wetland, Shuangtai estuary wetland, Yongyuanjiao wetland, Banhaibao wetland and Yalujiang estuary wetland, were selected as case study areas (Figure 1). Those cases were designed to cover as many types of coastal wetland as possible. Table 1 illustrates how each case represents specific types of coastal wetlands, including shallow marine waters, rocky coast, sandy stone sea beaches, sludge sea beaches, intertidal salt marshes, estuarine waters, and estuarine delta. 


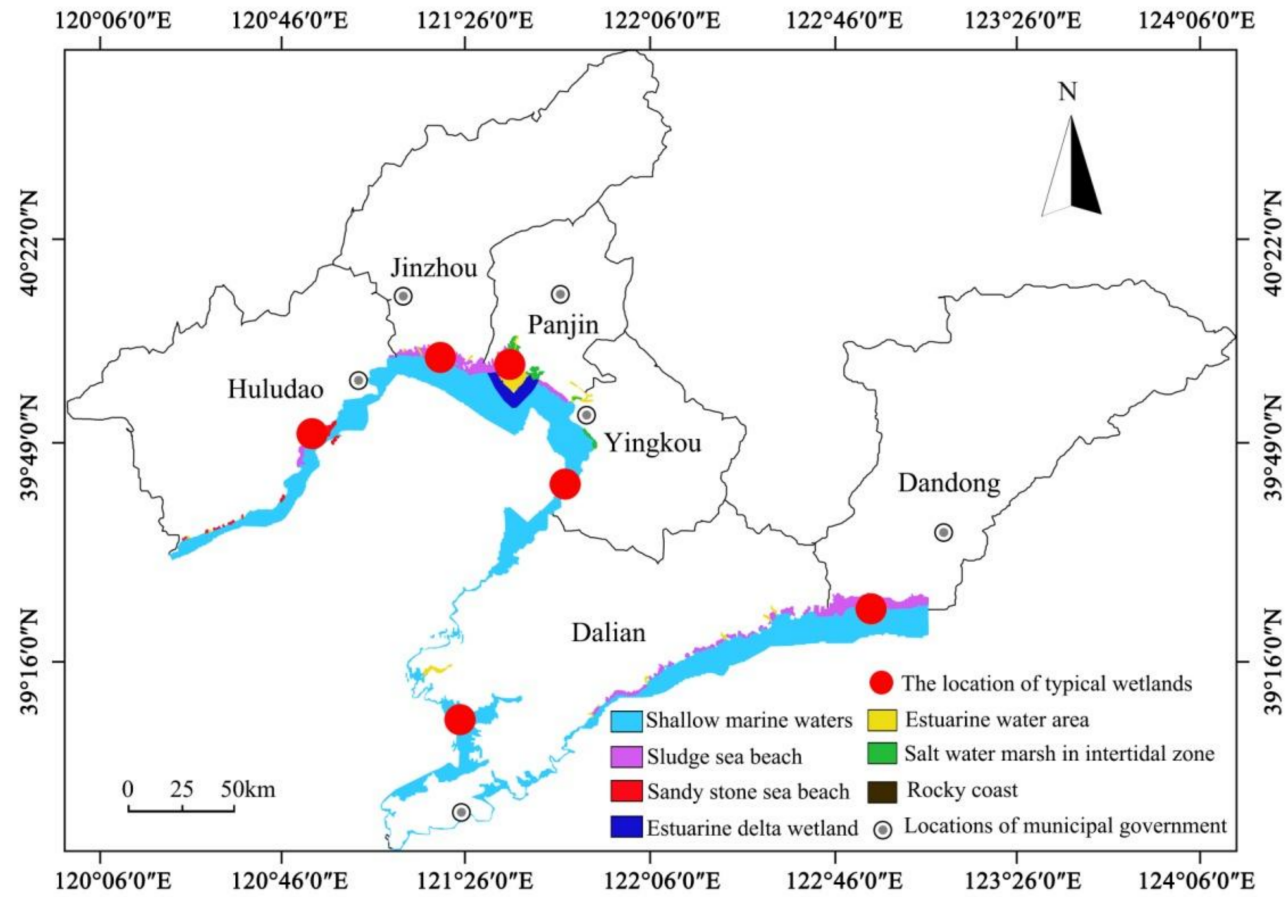

Figure 1. Different types and typical cases of coastal wetlands in Liaoning Province, China.

Table 1. The statistical acreage of different coastal wetland types in typical cases $\left(10^{4} \mathrm{ha}\right)$.

\begin{tabular}{cccccccccc}
\hline & & \multicolumn{7}{c}{ Coastal Wetland Types } & \\
\cline { 2 - 8 } No & Wetland Name & $\begin{array}{c}\text { Shallow } \\
\text { Marine } \\
\text { Waters }\end{array}$ & $\begin{array}{c}\text { Rocky } \\
\text { Coast }\end{array}$ & $\begin{array}{c}\text { Sandy } \\
\text { Stone Sea } \\
\text { Beaches }\end{array}$ & $\begin{array}{c}\text { Sludge } \\
\text { Sea } \\
\text { Beaches }\end{array}$ & $\begin{array}{c}\text { Intertidal } \\
\text { Salt } \\
\text { Marshes }\end{array}$ & $\begin{array}{c}\text { Estuarine } \\
\text { Waters }\end{array}$ & $\begin{array}{c}\text { Estuarine } \\
\text { Delta }\end{array}$ & Total \\
\hline 01 & $\begin{array}{c}\text { Liuguhe } \\
\text { wetland }\end{array}$ & - & - & 0.02 & - & - & 0.02 & - & 0.04 \\
\hline 02 & $\begin{array}{c}\text { Linghe estury } \\
\text { wetland }\end{array}$ & 5.48 & - & - & 1.20 & - & 0.09 & - & 6.77 \\
\hline 03 & $\begin{array}{c}\text { Shuangtai } \\
\text { estury wetland }\end{array}$ & 0.77 & - & - & 1.23 & 0.51 & 1.37 & 0.60 & 4.48 \\
\hline 04 & $\begin{array}{c}\text { Yongyuanjiao } \\
\text { wetland }\end{array}$ & - & - & - & - & 0.01 & - & - & 0.01 \\
\hline 05 & $\begin{array}{c}\text { Banhaibao } \\
\text { wetland }\end{array}$ & 6.49 & 0.02 & - & - & - & - & - & 6.51 \\
\hline 06 & $\begin{array}{c}\text { Yalujiang } \\
\text { estury wetland }\end{array}$ & 5.12 & - & - & 2.62 & - & - & - & 7.74 \\
\hline & Total & 17.86 & 0.02 & 0.02 & 5.05 & 0.52 & 1.48 & 0.60 & 25.55 \\
\hline
\end{tabular}

\subsection{The method for Empirical Measurement}

Based on the Millennium Ecosystem Assessment and double accounting [33-35], the dominant ecosystem services of the six cases can be classified as provisioning, regulating, and cultural services, containing eight more specific services: substance production, flood control, carbon sequestration, gas regulation, climate regulation, wave reduction, the addition of new land, recreation and scientific research $[9,11,36]$. The gross and separating ecosystem service value of each case was evaluated by empirical evaluation methods, which provide a control group for later model precision comparison. The economic values of substance production, gas regulation and the addition of new land in the coastal wetlands of Liaoning were calculated using the market price method [23]. The economic values of flood control and climate regulation were calculated using the replacement cost method [2], the economic 
value of water conservation was calculated by the shadow price method [37-39], the economic value of carbon sequestration was calculated using the carbon tax method $[40,41]$, the economic value of wave reduction was calculated using the expert evaluation method [42,43], and finally the economic values of recreation and scientific research were calculated using the travel cost and the simulate market methods [44,45].

\subsection{The Methods for Space-Scale Transform}

The techniques of scale transformation applied in this research belong to scaling up, which means estimating the ecological services of a large-scale wetland based on those of some small-scale wetlands that are more prone to be evaluated. We selected meta-analysis as one scaling up model because it is a useful tool to account the total value of the coastal wetland ecosystem services. Meanwhile, we used the method of wavelet transform to interpret multi-scale and non-stationary space-series data and reveal the features of coastal wetlands that are not apparent.

\subsubsection{The Meta-Analysis Method}

The process of meta-analysis includes three steps. The first step is related to data preparation: we carefully selected primary studies on the theme of coastal wetland evaluation (including both peer reviewed and non-peer reviewed studies) to populate our meta-analysis database. In the second step, we statistically estimated the impact of geospatial, environmental and socio-economic characteristics on coastal wetland ecosystem services. In the final step, the fitted model was used with the specific characteristics of the test areas in the typical cases to estimate the value of coastal wetland ecosystem services provided by each typical case.

A multi-variable model for the meta-regression analysis was conducted using a weighted least square (WLS) model in Equation (1):

$$
\operatorname{LnVij}=\beta_{0}+\beta_{w} X_{W i j}+\beta_{m} X_{m i j}+\beta_{c} X_{c i j}+U_{i j}
$$

where subscripts $i$ and $j$ refer to the ith observation in the jth study. The dependent variable Vij is the value of the coastal wetland ecosystem service for observation $i$ in study $j$, measured in 2013 USD per ha per year. $\beta_{0}$ is the intercept and $\beta_{w}, \beta_{m}$ and $\beta_{c}$ are the coefficients to be estimated for the explanatory (independent) variables including wetland characteristics, the evaluation techniques and environmental characteristics. As is the case for most meta-analyses on wetland ecosystem service values $[18,46]$, the economic values (Vij) were natural-log-transformed prior to analysis. $\mathrm{X} w$ represents wetland characteristics. $\mathrm{X} m$ represents the evaluation techniques, $\mathrm{Xc}$ represents environmental characteristics.

\subsubsection{The Wavelet Transform Method}

Based on spatial scale analysis and WaveCluster, we clustered the different geographic units of the coastal wetland in typical cases, and then transformed the value of the same cluster of the coastal wetland ecosystem services using layers of scales to account for the up-scaled values. Finally, we calculated each value of the coastal wetland ecosystem services in six typical cases. Because the number of data was small and the wavelet coefficients of each scale had strong correlations in each typical case, we used continuous wavelet transform. In this description, $f(x)$ denotes the spatial evolution results of coastal wetland ecosystem services. We can define continuous wavelet transform, which we denote by $\mathrm{W}(\mathrm{s}, \tau)$, as the complex conjugation of $f(x)$ with a detailed and translated "mother" wavelet function $\Psi$ s, $\tau(x)$ [47]:

$$
\Psi_{(s, \tau)}(x)=\frac{1}{\sqrt{s}} \Psi\left(\frac{x-\tau}{s}\right)
$$




$$
\mathrm{W}(\mathrm{s}, \tau)=\frac{1}{\sqrt{s}} \int_{-\infty}^{+\infty} f(x) \Psi\left(\frac{x-\tau}{s}\right) d x s>0
$$

where s represents the dilation (scale) of the wavelet function and $\tau$ represents the degree of distance translation along the series. The term $1 / \sqrt{\mathrm{s}}$ normalises the wavelet function energy at each scale. Equation (2) emphasizes that the wavelet function is in fact a "basis" function. W(s, $\tau$ ) in Equation (3) represents the coefficients of wavelet transform at different scales.

\subsection{The Method for Precision Comparison}

Three indicators were selected to verify the consistency between the simulation values and the empirical measured values, including the determination coefficient $\left(R^{2}\right)$, the root-mean-square error (RMSE), and the relative mean deviation (RMD). $R^{2}$, also called goodness-of-fit, represents the interpretive degree of independent variables to the dependent variable. Thus, the higher the value of $R^{2}$, the higher the precision. $R M D$ was used to measure the deviation between simulated values and measured values. The smaller the value of $R M D$, the higher the precision. Further, $R M D$ refers to the outcome of mean variation divided by average value. The smaller $R M D$ means closer repeated measured values. The equations of $R^{2}, R M S E$ and $R M D$ can be seen in Equations (4)-(6) below.

$$
\begin{gathered}
R^{2}=\left(\frac{\sum\left(O_{i}-\bar{O}\right)\left(P_{i}-\bar{P}\right)}{\sqrt{\sum\left(O_{i}-\bar{O}\right)^{2} \sum\left(P_{i}-\bar{P}\right)^{2}}}\right)^{2} \\
R M S E=\sqrt{\frac{\sum_{i=1}^{n}\left(P_{i}-O_{i}\right)^{2}}{n}} \\
R M D=\frac{100}{\bar{O}} \sum_{i=1}^{n} \frac{P_{i}-O_{i}}{n}
\end{gathered}
$$

where $O_{i}$ and $P_{i}$ represents the empirical measured values and simulated values, while $\bar{O}$ and $\bar{P}$ represents the average values of the empirical measured values and simulated values. $n$ represents the observation frequency.

\section{Results}

\subsection{The Measured Ecosystem Service Values of the Six Cases}

The various types of ecosystem service values of the six cases in Liaoning coastal wetlands were calculated based on the empirical measurement methods listed in Section 2.2. The detailed results are shown in Table 2. It can be seen that Yalujiang estuary had the highest gross ecosystem service value (3,464,077,670 USD), followed by Linghe estuary (3,397,896,440 USD). In contrast, Yongyuanjiao wetland had the lowest ecosystem service value $(9,708,738 \mathrm{USD})$, which was only $0.2 \%$ of that of Yalujiang estuary. However, the great disparity in value was related to the measured areas of cases rather than the wetland quality. The results of value on per unit area confirmed this deduction. The highest value on per unit area belonged to Yongyuanjiao $\left(965,372,168 \mathrm{USD} / 10^{4} \mathrm{ha}\right)$, while the lowest value on per unit area belonged to Banhaibao estuary $\left(374,433,657 \mathrm{USD} / 10^{4} \mathrm{ha}\right)$. In terms of the single ecological value, the average value peaked at $437,378,641$ USD in the value of carbon sequestration and reaches to the bottom at $62,297,735$ USD in the value of recreation and education. 
Table 2. The values of ecosystem services based on measured methods.

\begin{tabular}{ccccccc}
\hline & \multicolumn{7}{c}{ Wetland Values (USD) } \\
\cline { 2 - 7 } Ecosystem Services & Liuguhe & $\begin{array}{c}\text { Linghe } \\
\text { Estury }\end{array}$ & $\begin{array}{c}\text { Shuangtai } \\
\text { Estury }\end{array}$ & $\begin{array}{c}\text { Yongyuan } \\
\text { Jiao }\end{array}$ & Banhaibao & Yalujiangestury \\
\hline Substance production & $4,692,557$ & $748,705,502$ & $324,433,657$ & $1,456,311$ & $745,792,880$ & $723,948,220$ \\
Flood control & $8,252,427$ & $406,634,304$ & $388,673,139$ & $1,132,686$ & $330,420,712$ & $482,847,896$ \\
Carbon sequestration & $7,928,803$ & $833,009,709$ & $473,139,159$ & $2,427,184$ & $492,071,197$ & $815,372,168$ \\
Climate regulation & $4,045,307$ & $562,135,922$ & $368,608,414$ & $2,103,560$ & $362,783,172$ & $446,116,505$ \\
Gas regulation & $3,074,434$ & $440,453,074$ & $276,051,780$ & $1,294,498$ & $234,789,644$ & $352,912,621$ \\
Adding new lands & 161,812 & $65,533,981$ & $117,152,104$ & 161,812 & $58,414,239$ & $170,873,786$ \\
Wave reduction & $2,750,809$ & $249,190,939$ & $205,339,806$ & 161,812 & $87,378,641$ & $372,653,722$ \\
Recreation and education & 647,249 & $92,394,822$ & $62,297,735$ & 970,874 & $118,284,790$ & $99,190,939$ \\
Gross value & $31,553,398$ & $3,397,896,440$ & $2,215,857,605$ & $9,708,738$ & $2,429,773,463$ & $3,464,077,670$ \\
Value on per unit area & $789,320,388$ & $501,941,748$ & $494,660,194$ & $965,372,168$ & $374,433,657$ & $447,572,816$ \\
\hline
\end{tabular}

\subsection{The Ecosystem Service Values Stimulated by Meta-Analysis and Their Differences from Measured Values}

The ecosystem service values of the six cases were stimulated by meta-analysis based on the methods presented in Section 2.3.1, and the results are shown in Table 3. In general, the simulated values revealed a similar pattern to the empirical measured values. Yalujiang estuary had the highest gross ecosystem service value $(3,271,359,223$ USD), while Yongyuanjiao wetland had the lowest ecosystem service value (4,692,557 USD). The highest value on per unit area also belonged to Yongyuanjiao $\left(466,666,667 \mathrm{USD} / 10^{4} \mathrm{ha}\right)$. Similarly, the average value peaked at $453,074,434$ USD in the value of carbon sequestration and reached to the bottom at 61,003,236 USD in the value of recreation and education.

Table 3. The ecosystem services values of the six cases based on meta-analysis.

\begin{tabular}{|c|c|c|c|c|c|c|}
\hline \multirow[b]{2}{*}{ Ecosystem Services } & \multicolumn{6}{|c|}{ Wetland Values (USD) } \\
\hline & Liuguhe & $\begin{array}{l}\text { Linghe } \\
\text { Estuary }\end{array}$ & $\begin{array}{l}\text { Shuangtai } \\
\text { Estuary }\end{array}$ & $\begin{array}{c}\text { Yongyuan } \\
\text { Jiao }\end{array}$ & Banhaibao & $\begin{array}{l}\text { Yalujiang } \\
\text { Estuary }\end{array}$ \\
\hline Substance production & $2,588,997$ & $436,731,392$ & $269,255,663$ & 970,874 & $539,967,638$ & $609,385,113$ \\
\hline Flood control & $2,427,184$ & $498,381,877$ & $288,187,702$ & 647,249 & $491,423,948$ & $560,032,362$ \\
\hline Carbon sequestration & $4,045,307$ & $718,446,602$ & $479,773,463$ & $1,132,686$ & $675,566,343$ & $839,320,388$ \\
\hline Climate regulation & $3,074,434$ & $524,919,094$ & $346,116,505$ & 647,249 & $283,818,770$ & $236,731,392$ \\
\hline Gas regulation & $2,265,372$ & $361,326,861$ & $234,951,456$ & 485,437 & $360,355,987$ & $398,058,252$ \\
\hline Adding new lands & $1,132,686$ & $212,944,984$ & $133,656,958$ & 323,625 & $308,090,615$ & $372,006,472$ \\
\hline Wave reduction & 970,874 & $137,216,828$ & $103,074,434$ & 161,812 & $132,362,460$ & $15,4692,557$ \\
\hline Recreation and education & 970,874 & $83,009,709$ & $111,650,485$ & 323,625 & $69,255,663$ & $101,132,686$ \\
\hline Gross value & $17,475,728$ & $2,972,977,346$ & $1,966,666,667$ & $4,692,557$ & $2,860,841,424$ & $3,271,359,223$ \\
\hline Value on per unit area & $437,216,828$ & $439,158,576$ & $438,996,764$ & $466,666,667$ & $440,776,699$ & $422,653,722$ \\
\hline
\end{tabular}

Meanwhile, the data analysis results suggested generally that the simulated values of the six cases by meta-analysis were slightly lower than the empirical measured values. The model of meta-analysis was constructed based on the nation-wide cases and then implemented at the provincial level-Liaoning province. This process lowered the ecological values of the selected cases. The detailed comparisons between simulated values and measured values suggest differences exist in the veracity of simulation, either in different cases or targeting different single ecological values (see Figure 2). The smallest difference existed in the case of Shuangtai estuary wetland (Figure 2c) while the largest difference existed in Yongyuanjiao wetland (Figure 2d). From the aspect of wetland types, the method of meta analysis collected all the coastal wetland types to establish the database, so the wetlands had more types and the simulated values would be more closer to the measured values. Among six cases, Shuangtai estuary wetland included five coastal wetland types and Yongyuanjiao wetland included only one coastal wetland type (see Table 1). 

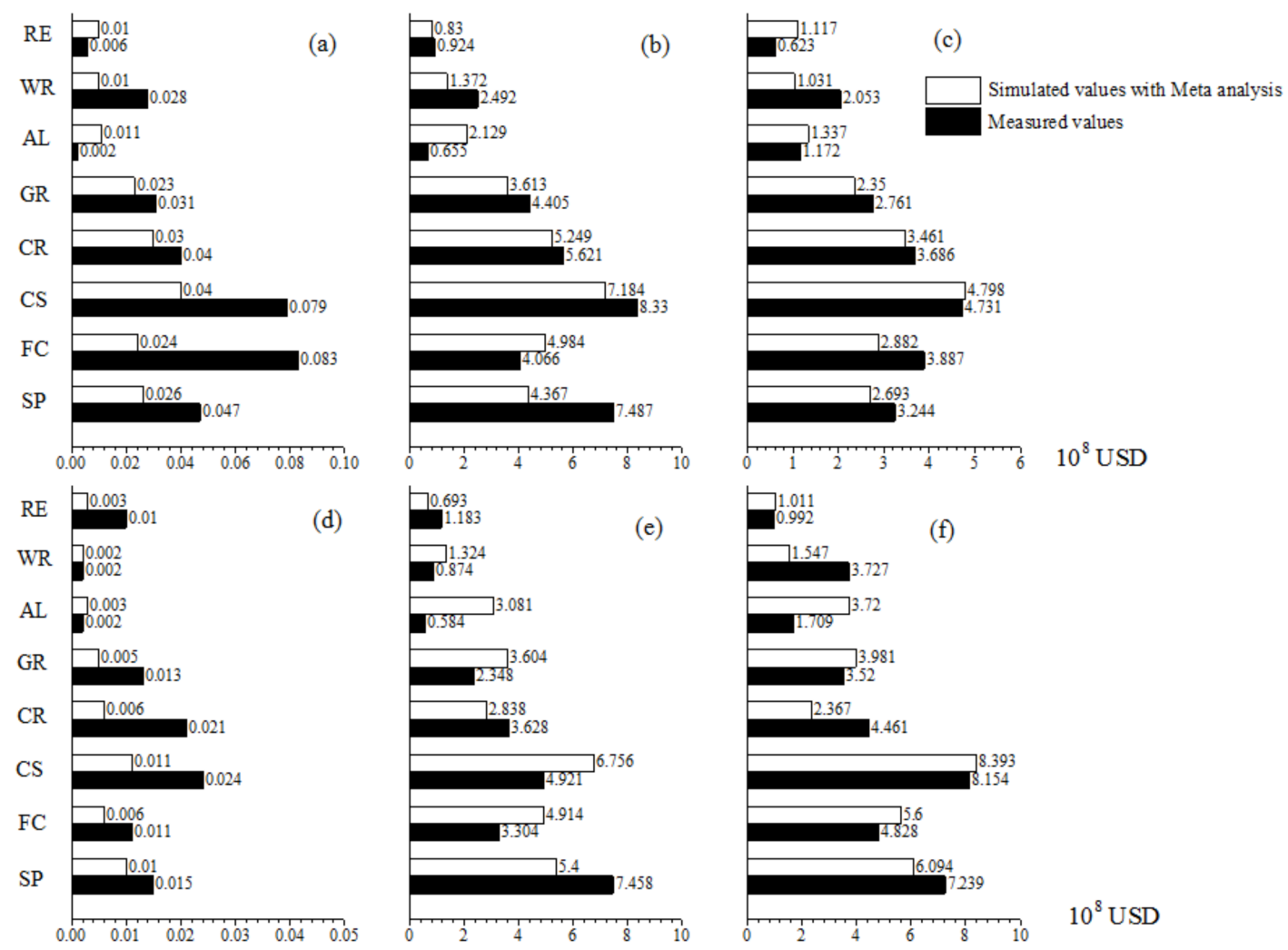

Figure 2. Simulated values with meta-analysis and measured values in typical coastal wetlands. Note: SP, Substance production; FC, Flood control; CS, Carbon sequestration; GR, Gas regulation; $\mathrm{CR}$, Climate regulation; WR, Wave reduction; AL, Adding new lands; RE, Recreation and Education. (a) Liuguhe wetland; (b) Linghe estuary wetland; (c) Shuangtai estuary wetland; (d) Yongyuanjiao wetland; (e) Banhaibao wetland; (f) Yalujiang estuary wetland.

In order to improve the comparability, we converted the values into per unit area $\left(1.0 \times 10^{8} \mathrm{USD} /\right.$ $10^{4}$ ha). Figure 3 illustrates the dispersion of the conserved simulated values from 48 groups of data. It can be seen that the distinction between simulated values and measured values varied from $-1.50 \times 10^{8} \mathrm{USD} / 10^{4}$ ha to $0.25 \times 10^{8} \mathrm{USD} / 10^{4}$ ha. The percentage of distinction between $-0.16 \times 10^{8} \mathrm{USD} / 10^{4}$ ha and $0.16 \times 10^{8} \mathrm{USD} / 10^{4}$ ha reached to $31.25 \%$.

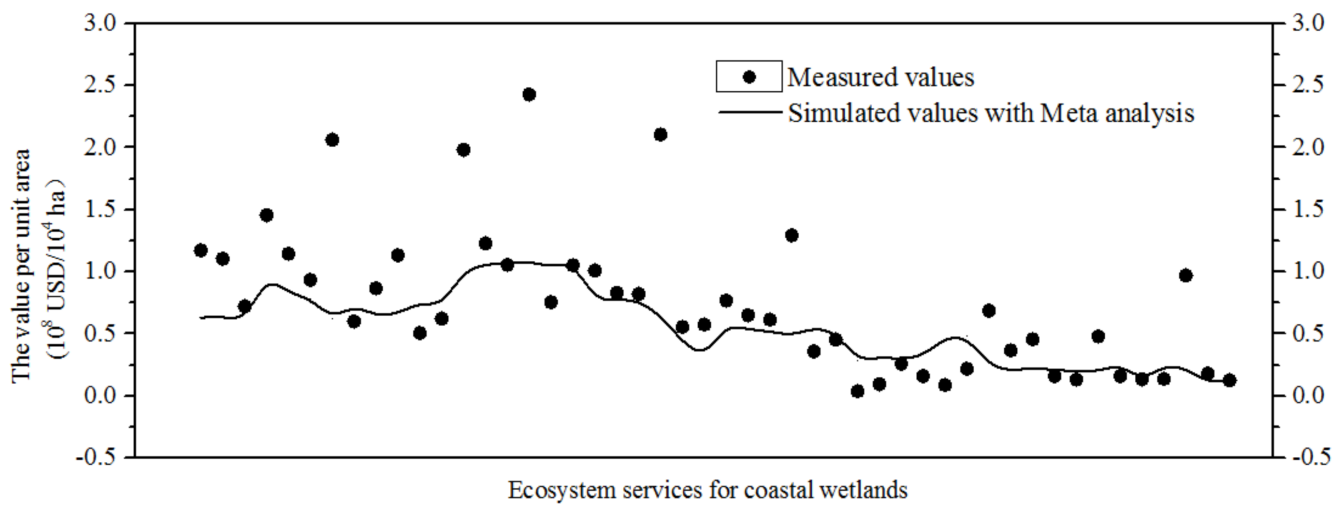

Figure 3. Values (per unit area) with simulated values in meta-analysis model and measured for coastal wetlands ecosystem services. 
3.3. The Ecosystem Service Values Stimulated by Wavelet Transform and Their Differences from Measured Values

The ecosystem service values of the six cases were stimulated by wavelet transform based on the methods presented in Section 2.3.2, and the results are shown in Table 4. The simulated values showed a slight difference from both the measured values and values simulated by wavelet transform. The Linghe estuary had the highest gross ecosystem service value $(3,199,676,375$ USD), followed by Yalujiang estuary $(3,193,851,133$ USD) with a narrow margin. The Yongyuanjiao wetland remained the lowest ecosystem service value $(8,414,239$ USD). The highest value on per unit area also belonged to Yongyuanjiao $\left(841,423,948 \mathrm{USD} / 10^{4} \mathrm{ha}\right)$, which was more than twice as much as the lowest value (Banhaibao, 334,304,207 USD $/ 10^{4}$ ha). The average value peaked at $421,359,223 \mathrm{USD} / 10^{4}$ ha in the value of substance production and reaches to the bottom at $37,864,078 \mathrm{USD} / 10^{4}$ ha in the value of adding new lands.

Table 4. The ecosystem services values of the six cases based on wavelet transform.

\begin{tabular}{ccccccc}
\hline & \multicolumn{5}{c}{ Wetland Values (USD/10 $\mathbf{h}$ ha) } \\
\cline { 2 - 7 } Ecosystem Services & Liuguhe & $\begin{array}{c}\text { Linghe } \\
\text { Estuary }\end{array}$ & $\begin{array}{c}\text { Shuangtai } \\
\text { Estuary }\end{array}$ & $\begin{array}{c}\text { Yongyuan } \\
\text { Jiao }\end{array}$ & Banhaibao & $\begin{array}{c}\text { Yalujiang } \\
\text { Estuary }\end{array}$ \\
\cline { 2 - 7 } & $4,530,744$ & $715,372,168$ & $350,161,812$ & $1,294,498$ & $717,961,165$ & $73,8834,951$ \\
Substance production & $7,766,990$ & $440,129,450$ & $369,093,851$ & 970,874 & $313,430,421$ & $446,763,754$ \\
$\quad$ Flood control & $5,987,055$ & $783,171,521$ & $431,229,773$ & $1,779,935$ & $453,883,495$ & $803,721,683$ \\
Carbon sequestration & $3,721,683$ & $541,100,324$ & $324,919,094$ & $2,265,372$ & $291,585,761$ & $393,042,071$ \\
Climate regulation & $2,427,184$ & $389,482,201$ & $243,042,071$ & 647,249 & $198,543,689$ & $373,462,783$ \\
$\quad$ Gas regulation & 161,812 & $42,233,010$ & $54,045,307$ & 323,625 & $16,828,479$ & $113,106,796$ \\
Adding new lands & $1,779,935$ & $207,605,178$ & $173,300,971$ & 323,625 & $70,550,162$ & $235,598,706$ \\
Wave reduction & 485,437 & $80,582,524$ & $47,249,191$ & 809,061 & $113,106,796$ & $89,320,388$ \\
Recreation and education & $26,860,841$ & $3,199,676,375$ & $1,993,042,071$ & $8,414,239$ & $2,175,889,968$ & $3,193,851,133$ \\
$\quad$ Gross value & $67,521,036$ & $472,653,722$ & $444,822,006$ & $841,423,948$ & $334,304,207$ & $412,621,359$ \\
Value on per unit area & & & & & & \\
\hline
\end{tabular}

The detailed comparisons between simulated values and measured values suggested differences exist in the veracity of simulation, either in different cases or targeting different single ecological values (see Figure 4). The smallest difference existed in the case of Linghe estuary wetland (Figure 4b) while the largest difference existed in Liuguhe wetland and Yongyuanjiao wetland (Figure 4a,d). From the aspect of wetland areas, the method of wavelet transform adopted belt transect lines for sampling, so the wetlands had more areas, and the simulated values would be more close to the measured values. Among six cases, Linghe estuary wetland had the largest areas $\left(6.77 \times 10^{4} \mathrm{ha}\right)$, Liuguhe wetland and Yongyuanjiao wetland had relatively smaller areas $\left(0.04 \times 10^{4}\right.$ ha \& $0.01 \times 10^{4}$ ha).

Figure 5 illustrates the dispersion of the conserved simulated values from 48 groups of data. It can be seen that the distinction between simulated values and measured values varied from $-0.65 \times 10^{8} \mathrm{USD} / 10^{4}$ ha to $0.16 \times 10^{8} \mathrm{USD} / 10^{4}$ ha. The percentage of distinction between $-0.16 \times 10^{8} \mathrm{USD} / 10^{4}$ ha and $0.16 \times 10^{8} \mathrm{USD} / 10^{4}$ ha reaches to $81.25 \%$, which is far more than that of meta-analysis. 

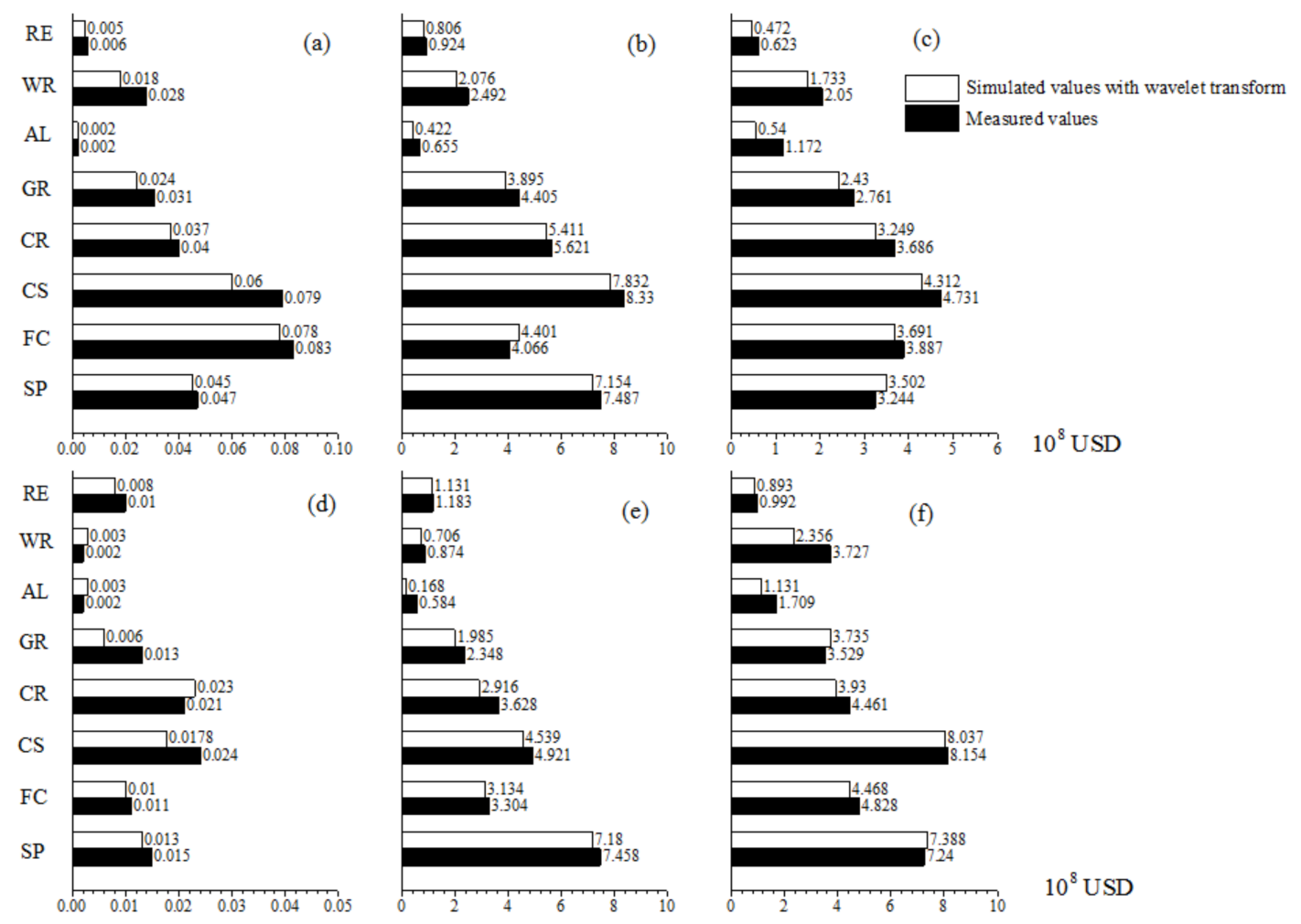

Figure 4. Simulated values with wavelet transform and measured ecosystem service values in classical coastal wetlands. Note: SP, Substance production; FC, Flood control; CS, Carbon sequestration; GR, Gas regulation; CR, Climate regulation; WR, Wave reduction; AL, Adding new lands; RE, Recreation and Education. (a) Liuguhe wetland; (b) Linghe estuary wetland; (c) Shuangtai estuary wetland; (d) Yongyuanjiao wetland; (e) Banhaibao wetland; (f) Yalujiang estuary wetland.

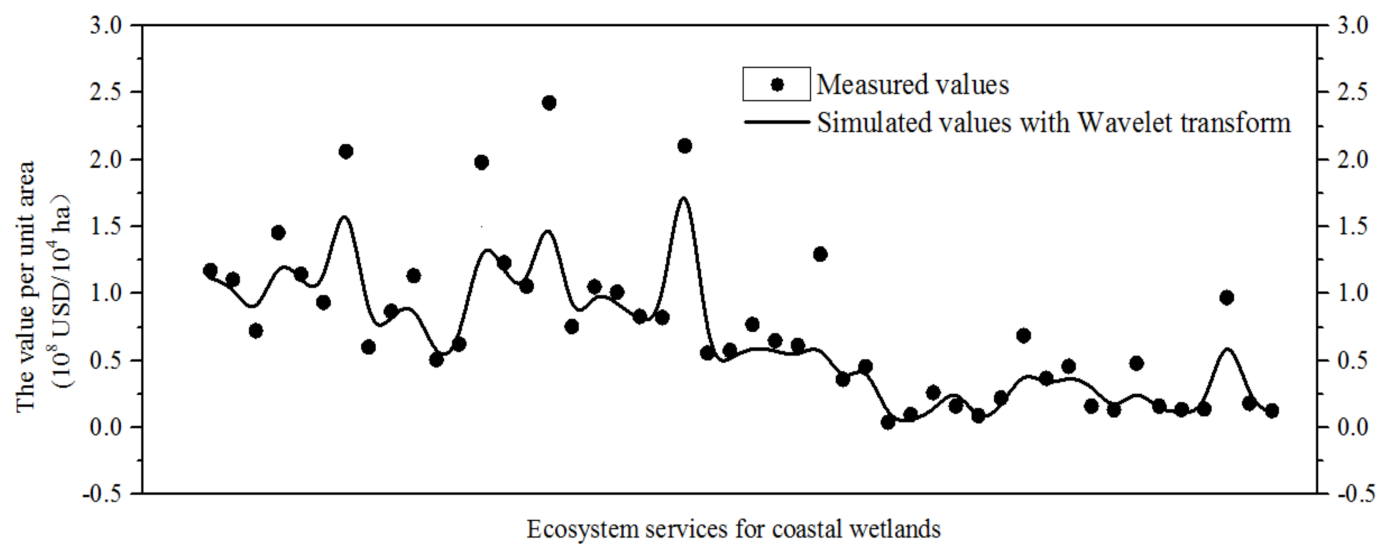

Figure 5. Values (per unit area) with simulated values in meta-analysis model and measured for coastal wetlands ecosystem services.

\subsection{The Precision Comparison between Meta-Analysis and Wavelet Transform}

The simulated values by meta-analysis and wavelet transform were correlated to the measured values, respectively, and the results are presented in Figure 6. The results showed both values simulated by meta-analysis and wavelet transform illustrate significant correlativity with the measured values. However, the $R^{2}$ of wavelet transform reached to 0.968 , which was higher than that of metaanalysis (0.712). 

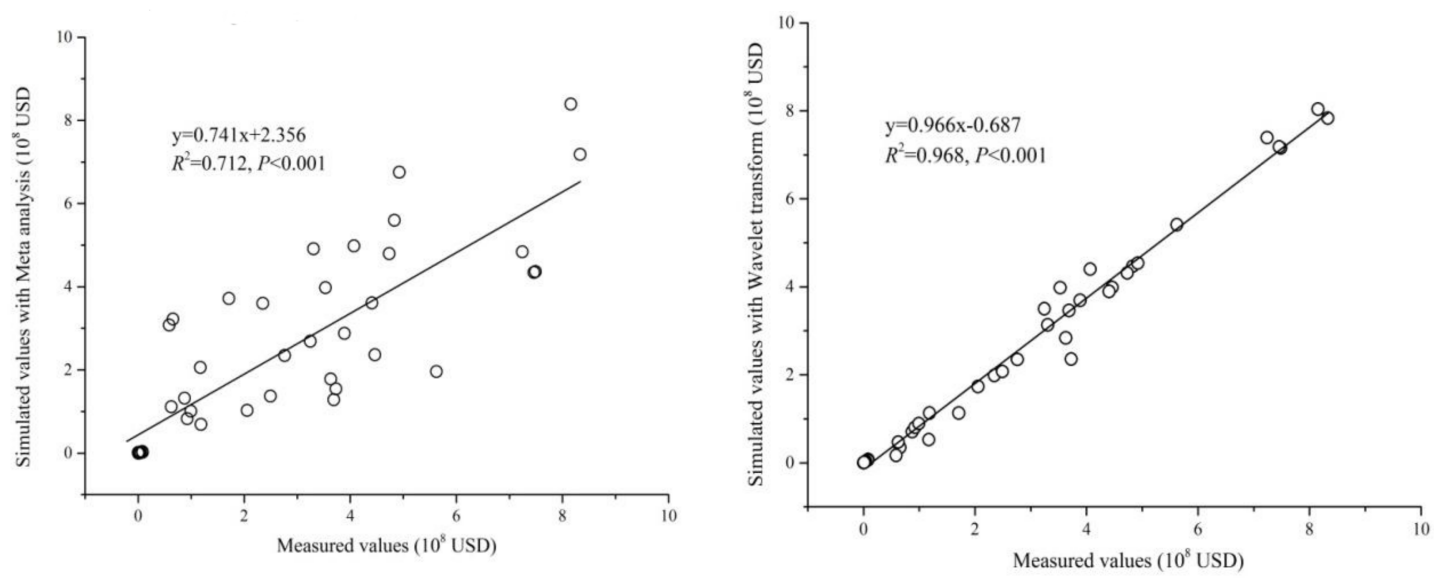

Figure 6. Precision comparisons of simulated values in two scale transform models and observed for coastal wetlands ecosystem services.

The values of eight single ecological services simulated by meta-analysis and wavelet transform were compared with the corresponding measured values (see Table 5). The data from the meta-analysis indicated that the simulated value of substance production, flood control, carbon sequestration, climate regulation and gas regulation had significant correlations with the measured values. The $R^{2}$ are 0.945 , $0.880,0.933,0.891$ and $0.853(p<0.01)$, RMSE were $9.96 \%, 5.67 \%, 5.50 \%, 5.75 \%$ and $4.05 \%$, while $R M D$ were $-27.08 \%, 13.80 \%, 3.60 \%,-20.08 \%$ and $3.74 \%$. The simulated value of wave reduction showed a certain correlation with the measured values.

Table 5. Precision comparisons of simulated values in two scale transform models with observed values for different ecosystem services.

\begin{tabular}{|c|c|c|c|c|c|c|}
\hline \multirow{2}{*}{ Observed vs. Simulated } & \multicolumn{3}{|c|}{ Meta Analysis } & \multicolumn{3}{|c|}{ Wavelet Transform } \\
\hline & $R^{2}$ & RMSE (\%) & $R M D(\%)$ & $R^{2}$ & RMSE (\%) & $R M D(\%)$ \\
\hline Substance production & $0.945^{* *}$ & 9.96 & -27.08 & $0.996^{* * *}$ & 1.33 & -0.82 \\
\hline Flood control & $0.880 * *$ & 5.67 & 13.80 & $0.988^{* * *}$ & 1.40 & -2.46 \\
\hline Carbon sequestration & 0.933 ** & 5.50 & 3.60 & $0.994^{* * *}$ & 1.20 & -4.14 \\
\hline Climate regulation & $0.891^{* *}$ & 5.75 & -20.08 & $0.987^{* * *}$ & 2.45 & -9.75 \\
\hline Gas regulation & 0.853 ** & 4.05 & 3.74 & $0.962 * * *$ & 2.21 & -6.45 \\
\hline Adding new lands & 0.612 & 5.87 & 98.35 & $0.932 * *$ & 2.54 & -47.10 \\
\hline Wave reduction & $0.712 *$ & 6.80 & -42.39 & $0.957 * *$ & 3.73 & -24.89 \\
\hline Recreation and education & 0.646 & 1.77 & -2.00 & $0.989 * * *$ & 0.55 & -11.30 \\
\hline
\end{tabular}

Note: ${ }^{* * *}$ stands for $p<0.001,{ }^{* *}$ stands for $p<0.01,{ }^{*}$ stands for $p<0.05$.

\section{Discussion}

In this paper, we compared simulated values calculated by two transform scale methods. Data was acquired from six coastal wetlands in Liaoning province. The obtained results showed that the precision of the wavelet transform model was higher than that of meta analysis.

By analysing those two space-scale methods, it can be found that the important step of meta analysis is determined by data collection. Thus, the themes of coastal wetland evaluation were carefully selected based on the previous studies [46,48-50]. Finally, a model based on the impact of geospatial, environmental and socio-economic characteristics on coastal wetland ecosystem services was constructed to calculate the value of each wetland type [36,51]. While wavelet transform is a relatively new and precise method for space series processing, wavelet transform allows for a completely flexible window function (called the mother wavelet), which can be changed over space based on scale and distance factors [20]. As the mother wavelet moves across space during the wavelet transform process, it generates several coefficients that represent the similarity between the space and 
mother wavelet at any specific scale [21,52]. Therefore, the wavelet transform method can identify nonlinear changes of values in different geographical spaces for coastal wetland ecosystem services in Liaoning province, China.

Thus, according to the theory of each method (Equations (1) and (3)), meta analysis would be affected by ecological factors and some other related environmental characteristics including wetland area, the GDP per capita, the population density, latitude, the distance from the wetland to the city centre and the evaluation year, while the wavelet transform would be mainly affected by two parameters including scale factors and distance factors. In order to precisely analyze the influence of each factor for two methods, sensitivity analysis method was used to test each possible parameter that affected the simulated result [53-55]. The sensitivity of parameter variables is the variation with the corresponding parameters, which increased by $10 \%$ [56-58]. This step is called local sensitivity analysis: total parameter variables are the changes with all parameters increased by $10 \%$ at the same time [59], and this step is called global sensitivity analysis. Through the model computation (Table 6), the random error from the affected factors with the method of meta analysis attained $+14.60 \%$, and $+8.70 \%$ for wavelet transform, which further proved that wavelet transform has higher simulation precision than meta analysis.

Table 6. The results of local sensitivity analysis for meta analysis and wavelet transform.

\begin{tabular}{ccccc}
\hline & \multicolumn{2}{c}{ Meta Analysis } & \multicolumn{2}{c}{ Wavelet Transform } \\
\hline \multirow{2}{*}{ Parameter Num } & $\begin{array}{c}\text { Parameter } \\
\text { Variables }\end{array}$ & Sensitivity (\%) & $\begin{array}{c}\text { Parameter } \\
\text { Variables }\end{array}$ & Sensitivity (\%) \\
& $\mathrm{V}_{\text {Size }}$ & -4.8 & Scale factors & +8.7 \\
01 & $\mathrm{~V}_{\mathrm{GDP}}$ & +7.0 & Distance factors & \\
02 & $\mathrm{~V}_{\text {Density }}$ & +9.1 & & \\
04 & $\mathrm{~V}_{\text {Latitude }}$ & -1.5 & & \\
05 & $\mathrm{~V}_{\text {Distance }}$ & +4.6 & & \\
06 & & $\mathrm{~V}_{\text {Year }}$ & +2.5 & \\
\hline
\end{tabular}

Note: The sensitivity of parameter variables was the change proportion with the corresponding parameters, which increased by $10 \%$; total parameter variables were the change proportion with all parameters, which increased by $10 \%$ at the same time. $\mathrm{V}_{\text {Size }}$ stands for the variable of wetland size, $\mathrm{V}_{\mathrm{GDP}}$ stands for the variable of the GDP per capita, $V_{\text {Density }}$ stands for the variable of the population density, $V_{\text {Latitude }}$ stands for the variable of Latitude, $\mathrm{V}_{\text {Distance }}$ stands for the variable of the distance from the wetland to the city center, $\mathrm{V}_{\text {Year }}$ stands for the variable of the evaluation year. Values for all important factors were printed in italics, with the most important factor being underlined. "+" stands for the increased change of sensitivity, also called the increased ratio of the wetland per unit value, "-" stands for the decreased change of sensitivity, also called the decreased ratio of the wetland per unit value.

By applying the meta analysis to simulate the whole provincial coastal wetland values, the results indicated that three services, named adding new lands, wave reduction, recreation and educationm had relatively lower precision (the $\mathrm{R}^{2}$ were $0.612,0.712$ and 0.646 ). The analysis of the database revealed the reasons for the lower precision may be the absence of raw data, which was also different from previous research $[19,60]$. Meanwhile, for the value of recreation and education, distinctions would exist between different coastal wetlands because of geomorphology and tourist attraction etc. [61-64]. There was no relationship between the value of recreation and education and wetland area, and social-economic characteristics around the wetlands. Thus, if we use the Meta analysis to evaluate a larger scale of wetlands, the ecosystem services with higher precision can directly apply the model. However, three services with relatively lower precision can combine with some other methods such as the method of direct extrapolation [65-69] to achieve better evaluation results.

This study contributes to a more precise evaluation model of wetland ecosystem services in the process of scale transform, providing information on wetland valuation and guidance on how evaluation should be conducted in larger wetlands. The accurate economic valuation of wetlands helps policy makers and planners realize the significant values of wetlands. It could also be necessary for 
wetland planning, conservation projects, and generally wise use. However, this study still has some limitations. For example, all types of coastal wetland should be selected in Liaoning province. Due to restrictions of labor inputs, the six cases we selected can only cover some types of coastal wetland. We hope that there will be some other more reasonable methods to resolve this limitation in the future.

\section{Conclusions}

In this paper, we compared the simulated values provided by two scale transform methods with the measured values in six typical coastal wetlands in Liaoning province, in order to acquire the precision of both methods. The total precision of the wavelet transform model (0.968) was higher than that of meta-analysis (0.712). In addition, the simulated values of single services such as substance production, flood control, carbon sequestration, gas regulation, and climate regulation were closer to the measured values using wavelet transform model. Therefore, this information could be useful for relevant decision makers to select appropriate methods in wetland evaluation projects at larger scales. The wavelet transform method would be helpful to calculate budgets and optimize project coats by providing more efficient and precise results.

Acknowledgments: This work was supported by National Key R\&D Program of China (2017YFC0506200). The authors would like to thank the staffs from administration of Shuangtai Estuary Wetland National Nature Reserve, Yalujiang Estuary Wetland National Nature Reserve and Banhaibao Nature Reserve in Liaoning province for their assistant in field and laboratory. We also thank Jingjing Yu, Zhaorui Liang, Yunmei Ping and Jingchao Tang for their valuable contributions.

Author Contributions: Baodi Sun, Yinru Lei and Lijuan Cui conceived of the study, participated in its design and coordination and drafted the manuscript. Wei Li and Xiaoming Kang participated in the data analysis and interpretation. Manyin Zhang carried out the experiments. All authors read and approved the final manuscript.

Conflicts of Interest: All authors have read and approved the final manuscript and have no conflicts of interest in regard to this research or its funding.

\section{References}

1. Adhikari, S.; Bajracharaya, R.M.; Sitaula, B.K. A review of carbon dynamics and sequestration in wetlands. Wetl. Ecol. Manag. 2009, 2, 42-46. [CrossRef]

2. Art, C.L. The Ramsar Convention Manual: A Guide to the Convention on Wetlands (Ramsar, Iran, 1971); Ramsar Convention Secretariat: Gland, Switzerland, 2006; Volume 21, pp. 691-693.

3. Bakhtadze, N.; Sakrutina, E. Applying the Multi-Scale Wavelet-Transform to the Identification of Non-linear Time-varying Plants. IFAC-PapersOnLine 2016, 49, 1927-1932. [CrossRef]

4. Barabás, G.; Pásztor, L.; Meszéna, G.; Ostling, A. Sensitivity analysis of coexistence in ecological communities: Theory and application. Ecol. Lett. 2014, 17, 1479-1494. [CrossRef] [PubMed]

5. Barbier, E.B. Valuing ecosystem services as productive inputs. Econ. Policy 2007, 22, 177-229. [CrossRef]

6. Barbier, E.B.; Koch, E.W.; Silliman, B.R.; Hacker, S.D.; Wolanski, E.; Primavera, J.; Granek, E.; Polasky, S.; Aswani, S.; Cramer, L.A.; et al. Coastal ecosystem-based management with nonlinear ecological functions and values. Science 2008, 319, 321-323. [CrossRef] [PubMed]

7. Boutin, C.; Carpenter, D.J. Assessment of wetland/upland vegetation communities and evaluation of soil-plant contamination by polycyclic aromatic hydrocarbons and trace Metals in regions near oil sands mining in Alberta. Sci. Total Environ. 2017, 576, 829-839. [CrossRef] [PubMed]

8. Brander, L.M.; Bräuer, I.; Gerdes, H.; Ghermandi, A.; Kuik, O. Using Meta-analysis and GIS for value transfer and scaling up: Valuing climate change induced losses of European wetlands. Environ. Resour. Econ. 2012, 52, 395-413. [CrossRef]

9. Bull, J.W.; Milner-Gulland, E.J.; Suttle, K.B.; Singh, N.J. Comparing biodiversity offset calculation methods with a case study in Uzbekistan. Biol. Conserv. 2014, 178, 2-10. [CrossRef]

10. Camachovaldez, V.; Ruizluna, A.; Ghermandi, A.; Nunes, P.A.L.D. Valuation of ecosystem services provided by coastal wetlands in northwest Mexico. Ocean Coast. Manag. 2013, 78, 1-11. [CrossRef]

11. Camachovaldez, V.; Ruizluna, A.; Ghermandi, A.; Berlangarobles, C.A.; Nunes, P.A. Effects of land use changes on the ecosystem service values of coastal wetlands. J. Environ. Manag. 2014, 54, 852-864. [CrossRef] [PubMed] 
12. Chaikumbung, M.; Doucouliagos, H.; Scarborough, H. The economic value of wetlands in developing countries: A meta-regression analysis. Ecol. Econ. 2016, 124, 164-174. [CrossRef]

13. Costanza, R. Ecosystem services: Multiple classification systems are needed. Biol. Conserv. 2008, 141, 350-352. [CrossRef]

14. Costanza, R.; d'Arge, R.; De Groot, R.; Farber, S.; Grasso, M.; Hannon, B.; Limburg, K.; Naeem, S.; O'Neill, R.; Paruelo, J.; et al. The value of the world's ecosystem services and natural capital. Nature 1997, 25, 3-15. [CrossRef]

15. Cui, L.J.; Sun, B.D.; Li, W.; Pang, B.L.; Lei, Y.R.; Ma, M.Y.; Ma, Q.F. Evaluation of ecosystem services value of the Zoigê Wetland Nature Reserve by multiple criteria. Wetl. Sci. 2016, 14, 145-156.

16. Eppink, F.V.; Brander, L.M.; Wagtendonk, A.J. An Initial Assessment of the Economic Value of Coastal and Freshwater Wetlands in West Asia. Landscape 2014, 3, 557-573. [CrossRef]

17. Funashima, Y. Time-varying leads and lags across frequencies using a continuous wavelet transform approach. Econ. Model. 2017, 60, 24-28. [CrossRef]

18. Gabler, C.A.; Osland, M.J.; Grace, J.B.; Stagg, C.L.; Day, R.H. Erratum: Macroclimatic change expected to transform coastal wetland ecosystems this century. Nat. Clim. Chang. 2017, 7, 142-147. [CrossRef]

19. Gardner, R.C.; Davidson, N.C. The Ramsar Convention; Springer: Dordrecht, The Netherlands, 2011.

20. Ghermandi, A.; Ding, H.; Nunes, P.A.L.D. The social dimension of biodiversity policy in the European Union: Valuing the benefits to vulnerable communities. Environ. Sci. Policy 2013, 33, 196-208. [CrossRef]

21. Goh, S.S.; Goodman, T.N.T.; Lee, S.L. Full length article: Singular integrals, scale-space and wavelet transforms. J. Approx. Theory 2013, 176, 68-93. [CrossRef]

22. Goodchild, M.F. Challenges in geographical information science. Proc. Math. Phys. Eng. Sci. 2011, 467, 2431-2443. [CrossRef]

23. Graham, S.A.; Mendelssohn, I.A. Coastal wetland stability maintained through counter balancing accretionary responses to chronic nutrient enrichment. Ecology 2014, 95, 3271-3283. [CrossRef]

24. Huang, J.L.; Du, P.F.; He, W.Q.; Ao, Z.D.; Wang, H.C.; Wang, Z.S. Local sensitivity for urban rainfall runoff modelling. China Environ. Sci. 2007, 27, 549-553.

25. Ivajnšič, D.; Kaligarič, M. How to preserve coastal wetlands, threatened by climate change-driven rises in sea level. Environ. Manag. 2014, 54, 1-14. [CrossRef] [PubMed]

26. Jiang, B.; Ouyang, Z.Y.; Miao, H.; Zhuang, C. Ecosystem services valuation of the Haihe River basin wetlands. Acta Ecol. Sin. 2011, 31, 2236-2244.

27. Jing, F.R.; Sun, H.; Yuan, C. Spatial structure analysis of tourism resource attraction in Chengdu. Resour. Sci. 2017, 39, 303-313.

28. Khatami, R.; Mountrakis, G.; Stehman, S.V. A Meta-analysis of remote sensing research on supervised pixel-based land-cover image classification processes: General guidelines for practitioners and future research. Remote Sens. Environ. 2016, 177, 89-100. [CrossRef]

29. King, R.S.; Richardson, C.J.; Urban, D.L.; Romanowicz, E.A. Spatial Dependency of Vegetation Environment Linkages in an Anthropogenically Influenced Wetland Ecosystem. Ecosystem 2004, 7, 75-97. [CrossRef]

30. Krause, S.; Hannah, D.M.; Sadler, J.P.; Wood, P.J. Ecohydrology on the edge: Interactions across the interfaces of wetland, riparian and groundwater-based ecosystems. Ecohydrology 2011, 4, 477-480. [CrossRef]

31. Lamsal, P.; Atreya, K.; Pant, K.P. Tourism and wetland conservation: Application of travel cost and willingness to pay an entry fee at Ghodaghodi Lake Complex, Nepa. Nat. Resour. Forum 2016, 40, 51-61. [CrossRef]

32. Ledoux, L.; Turner, R.K. Valuing ocean and coastal resources: A review of practical examples and issues for further action. Ocean Coast. Manag. 2002, 45, 583-616. [CrossRef]

33. Li, K.; Cui, L.J.; Li, W.; Kang, X.M.; Zhang, Y.Q. Removing double counting in wetland ecosystem services valuation based on emergyalge-bra. Chin. J. Ecol. 2016, 35, 1108-1116.

34. Li, W.; Cui, L.J.; Pang, B.L.; Ma, M.Y.; Kang, X.M. Thinking of solving double counting in wetland ecosystem services valuation. Ecol. Environ. Sci. 2014, 23, 1716-1724.

35. Litaor, M.I.; Barnea, I.; Reichmann, O.; Zohar, I. Evaluation of the ornithogenic influence on the trophic state of East Mediterranean wetland ecosystem using trend analysis. Sci. Total Environ. 2016, 539, 231-240. [CrossRef] [PubMed]

36. MA. Ecosystems and Human Well-Being; Island Press: Washington, DC, USA, 2005. 
37. Mitsch, W.J.; Zhang, L.; Waletzko, E.; Bernal, B. Validation of the ecosystem services of created wetlands: Two decades of plant succession, nutrient retention, and carbon sequestration in experimental riverine marshes. Ecol. Eng. 2014, 72, 11-24. [CrossRef]

38. Moreno-Mateos, D.; Barbier, E.B.; Jones, P.C. Anthropogenic ecosystem disturbance and the recovery debt. Nat. Commun. 2017, 8, 14163. [CrossRef] [PubMed]

39. Morenomateos, D.; Power, M.E.; Comín, F.A.; Yockteng, R. Structural and functional loss in restored wetland ecosystems. PLoS Biol. 2012, 10, 1-8.

40. Mount, N.J.; Tate, N.J.; Sarker, M.H.; Thorne, C.R. Evolutionary, multi-scale analysis of river bank line retreat using continuous wavelet transforms: Jamuna River, Bangladesh. Geomorphology 2013, 183, 82-95. [CrossRef]

41. Nakagawa, S.; Noble, D.W.A.; Senior, A.M.; Lagisz, M. Meta-evaluation of meta-analysis: Ten appraisal questions for biologists. BMC Biol. 2017, 15, 18. [CrossRef] [PubMed]

42. Ouyang, Z.Y.; Zheng, H. Ecological mechanisms of ecosystem services. Acta Ecol. Sin. 2009, 29, 6183-6188.

43. Pavlineri, N.; Skoulikidis, N.T.; Tsihrintzis, V.A. Constructed floating wetlands: A review of research, design, operation and management aspects, and data meta-analysis. Chem. Eng. J. 2016, 308, 1120-1132. [CrossRef]

44. Pour, M. Simultaneous application of time series analysis and wavelet transform for determining surface roughness of the ground workpieces. Int. J. Adv. Manuf. Technol. 2016, 85, 1793-1805. [CrossRef]

45. Quintas, S.C.; Martín, L.B.; Santos, M.F. Ecosystem services values in Spain: A Meta-analysis. Environ. Sci. Policy 2016, 55, 186-195. [CrossRef]

46. Radaev, N.N. Accuracy in expert evaluation of object states by pairwise comparison with quantitative preference estimation. Meas. Tech. 2007, 50, 908-915. [CrossRef]

47. Rao, N.S.; Ghermandi, A.; Portela, R.; Wang, X. Global values of coastal ecosystem services: A spatial economic analysis of shoreline protection values. Ecosyst. Serv. 2015, 11, 95-105. [CrossRef]

48. Roebeling, P.; Abrantes, N.; Ribeiro, S.; Almeida, P. Estimating cultural benefits from surface water status improvements in freshwater wetland ecosystems. Sci. Total Environ. 2016, 545-546, 219-226. [CrossRef] [PubMed]

49. Robertson, A.L.; Wood, P.J. Ecology of the hyporheic zone: Origins, current knowledge and future directions. Fundam. Appl. Limnol. 2010, 176, 279-289. [CrossRef]

50. Rong, Q.; Liu, J.; Cai, Y.; Lu, Z.; Zhao, Z.; Yue, W.; Xia, J. Leaf carbon, nitrogen and phosphorus stoichiometry of Tamarix chinensis, Lour. in the Laizhou Bay coastal wetland, China. Ecol. Eng. 2015, 76, 57-65. [CrossRef]

51. Sanders, C.J.; Santos, I.R.; Maher, D.T.; Sadat-Noori, M.; Schnetger, B.; Brumsack, H.J. Dissolved iron exports from an estuary surrounded by coastal wetlands: Can small estuaries be a significant source of Fe to the ocean? Mar. Chem. 2015, 176, 75-82. [CrossRef]

52. Saunders, C.J.; Gao, M.; Jaffé, R. Environmental assessment of vegetation and hydrological conditions in Everglades freshwater marshes using multiple geochemical proxies. Aquat. Sci. 2015, 77, 1-21. [CrossRef]

53. Serafinska, A.; Özenç, K.; Kaliske, M. A coupled approach of optimization, uncertainty analysis and configurational mechanics for a fail-safe design of structures. Int. J. Numer. Methods Eng. 2017, 109, 125-152. [CrossRef]

54. Song, Y.Q.; Zhang, X.L. A multi-dimensional approach for wetland ecosystem service valuation. Acta Ecol. Sin. 2014, 34, 1352-1360.

55. Sun, B.D.; Cui, L.J.; Lei, Y.R.; Li, W.; Kang, X.M. Analyzing about the Assessment of the Recreational Value in Liaoning Shuangtai Estuary Wetland. Wetl. Sci. Manag. 2015, 11, 16-19.

56. Sun, B.D.; Cui, L.J.; Li, W.; Kang, X.M. A method of scale conversion for wetland valuation: An overview on Meta-analysis. Wetl. Sci. Manag. 2016, 3, 58-62.

57. Sun, B.D.; Cui, L.J.; Li, W.; Kang, X.M. Dominant ecosystem services of shuangtai estuary wetland based on different beneficiaries. Chin. J. Ecol. 2017, 36, 164-171.

58. Sun, B.D.; Cui, L.J.; Li, W.; Kang, X.M.; Pan, X.; Lei, Y.R. A meta-analysis of coastal wetland ecosystem services in Liaoning Province, China. Estuar. Coast. Shelf Sci. 2018, 200, 349-358. [CrossRef]

59. TEEB (The Economics of Ecosystems and Biodiversity). Mainstreaming the Economics of Nature: A Synthesis of the Approach, Conclusions and Recommendations of TEEB; United Nation Environment Program: Nagoya, Japan, 2010.

60. Trebitz, A.S.; Brazner, J.C.; Cotter, A.M.; Knuth, M.L.; Morrice, J.A.; Petersom, G.S.; Sierszen, M.E.; Thompson, J.A.; Kelly, J.R. Water Quality in Great Lakes Coastal Wetlands: Basin-wide Patterns and Responses to an Anthropogenic Disturbance Gradient. J. Great Lakes Res. 2016, 33, 67-85. [CrossRef] 
61. Wittmann, F.; Householder, E.; Wittmann, A.D.O.; Lopes, A.; Junk, W.J.; Piedade, M.T.F. Implementation of the ramsar convention on South American wetlands: An update. Res. Rep. Biodivers. Study 2015, 4, 47-58. [CrossRef]

62. Yang, W.; Lang, Y.H.; Bai, J.; Li, Z.Y. Quantitative evaluation of carcinogenic and non-carcinogenic potential for PAHs in coastal wetland soils of China. Ecol. Eng. 2015, 74, 117-124. [CrossRef]

63. Yao, J.; Sánchez-Pérez, J.M.; Sauvage, S.; Teissier, S.; Attard, E.; Lauga, B.; Duran, R.; Julien, F.; Bernard-Jannin, L.; Ramburn, H.; et al. Biodiversity and ecosystem purification service in an alluvial wetland. Ecol. Eng. 2017, 103, 359-371. [CrossRef]

64. Zhang, J.L.; Li, Y.P.; Huang, G.H.; Baetz, B.W.; Liu, J. Uncertainty analysis for effluent trading planning using a Bayesian estimation-based simulation-optimization modeling approach. Water Res. 2017, 116, 159-181. [CrossRef] [PubMed]

65. Zhang, X.; Lu, X. Multiple criteria evaluation of ecosystem services for the Ruoergai Plateau Marshes in southwest China. Ecol. Econ. 2010, 69, 1463-1470. [CrossRef]

66. Zhang, Y.R. Evaluation of Lake and Marsh Wetland Ecosystem Services in China Based on Meta Analysis for Benefittransfer. Ph.D. Thesis, Capital Normal University, Beijing, China, May 2014.

67. Zhao, H.T.; Wang, L.R. Classification of coastal wetland in China. Mar. Sci. Bull. 2000, 19, 72-82.

68. Zorrilla, M.P.; Palomo, I.; Gómez, E.B.; Martín, B.L.; Lomas, P.L.; Montes, C. Effects of land-use change on wetland ecosystem services: A case study in the donana marshes (swspain). Landsc. Urban Plan. 2014, 122, 160-174. [CrossRef]

69. Zou, Y.A.; Niu, J.Y.; Tang, C.D.; Pei, E.L.; Tang, S.X.; Lu, S. Shorebird habitat changes in the East Asian-Australasian Flyway: A case study of the stopover site in Chongming Dongtan. Chin. J. Ecol. 2014, 33, 3300-3307.

(C) 2018 by the authors. Licensee MDPI, Basel, Switzerland. This article is an open access article distributed under the terms and conditions of the Creative Commons Attribution (CC BY) license (http:/ / creativecommons.org/licenses/by/4.0/). 